\title{
The internalization of conservation mindset in disruptive era
}

\author{
Fathur Rokhman ${ }^{*}$, Amin Retnoningsih and Hendi Pratama \\ Universitas Negeri Semarang, Indonesia
}

\begin{abstract}
Environmental conservation is not all about physical preservation of our surroundings but also the development of the human components of the conservation. Only with the right mindset, conservation can be maintained and, in the end, sustainable. Conservation awareness has been a common theme for academics and environmental activists but it is not always the case for the common masses. This paper focuses on illustrating the challenges and strategies of planting the appropriate mindset of conservation to young generation in Indonesia. Most of examples and cases provided in this paper are taken from our experience in managing the university we currently work for.
\end{abstract}

\section{Introduction}

Humans are changing the face and the composition of the planet but they are rarely aware of that fact. Most of the times, a single human think that what he/she does can only affect his/her local surrounding. In accumulation, human population accrue their 'local' destruction of the environment to the global level. Take farmers and palm industry in Kalimantan as an example. Every farmer thinks that burning a little bit of forest will not harm the planet and a single industry can only take a few acres of lands. However, when the deeds have been conducted en masse and going for some years the following effects have shown up [1].

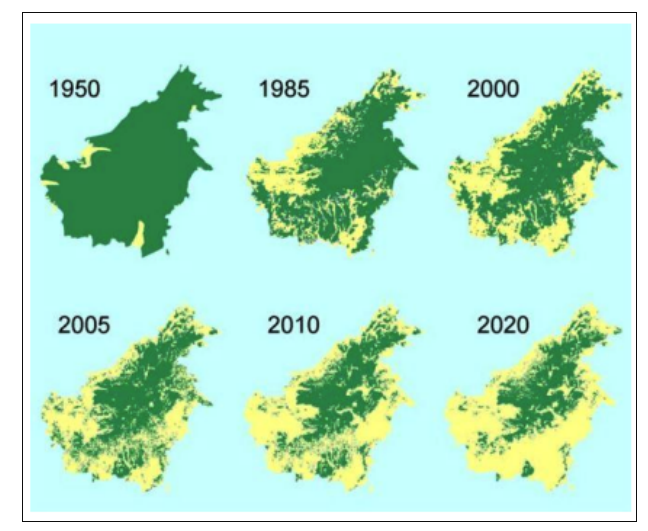

Fig. 1. Satellites images of Kalimantan's forests over the year

That is the first challenge among many that we have to tackle as human beings. As a rule if thumbs, humans are not able to behave and act responsibly in global level. People will not burn their fuel tank because of obvious reason that they can predict the immediate effect of their action. However, people will not suddenly stop to buy and drive cars even if they know that their cars contribute to global warming via their exhaust gases. This is because people are not able to fathom effects which have no immediate context with their actions. Kahneman (2011) states that this phenomenon is caused by evolutionary process of our brain [6]. Homo Sapiens' brain has been hardwired effectively to detect danger of predators in the past. Human brain has been trained to decide immediate effect of a response via sensors in their body and create fight or flight reaction. The brain has remained that way for thousand years and it will not change radically in the near future.

The second challenge of conservation the pressure of economic growth for the environment. The main cause of this phenomenon is the fact that liberal approach to happiness has been accepted as a global norm. Everyone has the right to pursue their happiness via possessions and accumulation of wealth. Majority of human population has agreed to the mechanism of 'better economy for better life'. However, economic growth itself is not without shortcomings. For every incremental change of our economy, there are natural resources need to be sacrificed. People cut trees for houses. People dig the earth to extract metals for car making. Every single economical gain shall hurt the environment with different levels of suffering.

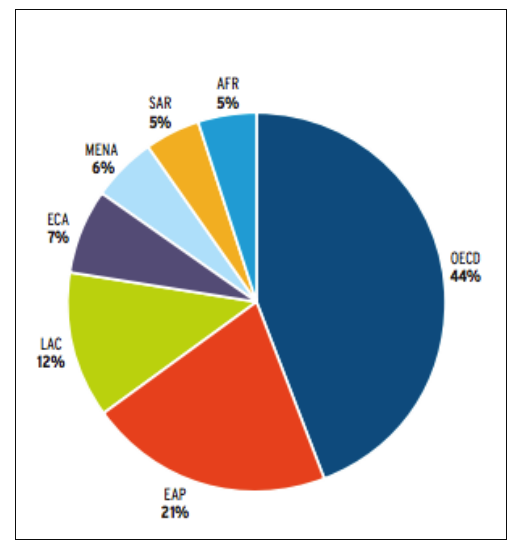

Fig. 2. Waste generation based on regions [9].

\footnotetext{
Corresponding author: fathurrokhman@,mail.unnes.ac.ids
} 
Fig. 2. shows the distribution of waste generation around the world. The strange fact is that the Organization for Economic Cooperation and Development (OECD) whose members are mostly advanced countries has dominated the world's waste generation. We call it strange because OECD countries are the ones who have the technology and upper hand understanding on conservation. However, they have failed to curb their waste production. This evidence supports our case earlier that economic growth has always hurt the environment. OECD countries are among the richest countries in the world consequently hurt the environments the hardest.

The third challenge of conservation in modern era is that we do not have the passion of creating the technology to help our planet. The existing technology we have now is not helping the environment. The green technology we create is only reducing, restoring or sometimes hiding the damages we have created. We do not have the technology to create fresh air, we somehow have technology or initiatives to reduce pollution [4]. We do not have the technology to create water, we only have the technology to reduce toxic and waste in our ocean. Even then, the technology is still not effective as expected [8].

\section{The 'ideal' conservation}

Conservation has many forms but there are guiding principles which bind the forms together. Conservation is the management of human use of the biosphere so that it may yield the greatest sustainable benefit to present generations while maintaining its potential to meet the needs and aspirations of future generations.

There are two types of basic conservations: in situ conservation and ex situ conservation. In situ conservation is the conservation of species in their natural habitat for example natural parks, nature reserves. Ex situ conservation is conserving species in isolation of their natural habitat for example zoos, botanical gardens, seed banks [3].

Modern conservation needs more than just in situ and ex situ conservation because conservation is not always about biodiversity. Conservation is about the humans too. It is also about cultural conservation [5]. At its very core, cultural conservation has some values:

(a) Aesthetic Value: healthy environment is manifested in beauty.

(b) Recreational Value: preserved nature is a soul entertainment for humans.

(c) Educational and Scientific Value: preserving nature shall be based on education and science

(d) Theurapeutic and Character-Building Value: preserved nature served as therapy and character building for humans.

\section{Conservation at our place}

At our university, conservation has become a crucial part of our vision. The vision of Universitas Negeri Semarang (UNNES) is to become a conservation university with international reputation. Conservation has been the core of the vision itself. Rooted from an education university, we realize that we do not have the same capacity of environmental research if we compare ourselves with other all-round universities which have environment major or green engineering major. At first, it became our main obstacles of achieving our vision. However, we have the commitment to compensate this shortcoming with the adoption of values and cultural conservation like the ones explained by Howland and Rowles (2004). In interpreting the four values of cultural environment we have done the following actions.

In implementing aesthetic value, UNNES has arranged all its gardens and trees in beautiful constellation. We have the belief that tidy arrangement of gardens and trees are the realization of healthy environment.

In implementing recreational values, we have developed eco-education teaching styles around campus. We have conducted classes outdoors. We also invite students from other campuses and even students from high school to visit our university.

In implementing educational and scientific value we have embedded the value of conservations into teaching. Lecturers are obliged to accommodate conservation values to teaching and learning process. Conservation is explicitly mentioned and elaborated in the main curriculum, syllabus, lesson plan and teaching media. In implementing character-building value, we have assigned each faculty with one main character to develop. In total, there are eight main characters to developed in all faculties: inspiration, humanity, compassion, innovation, creativity, sportiveness, honesty and justice.

\section{Customized disruptive era}

conservation

in

All those efforts, which have been explained before in cultural values, must be redesigned to fit in the framework of disruptive innovation [7]. Disruptive innovation will not allow the same strategy to be repeated over and over in an ever-changing environment.

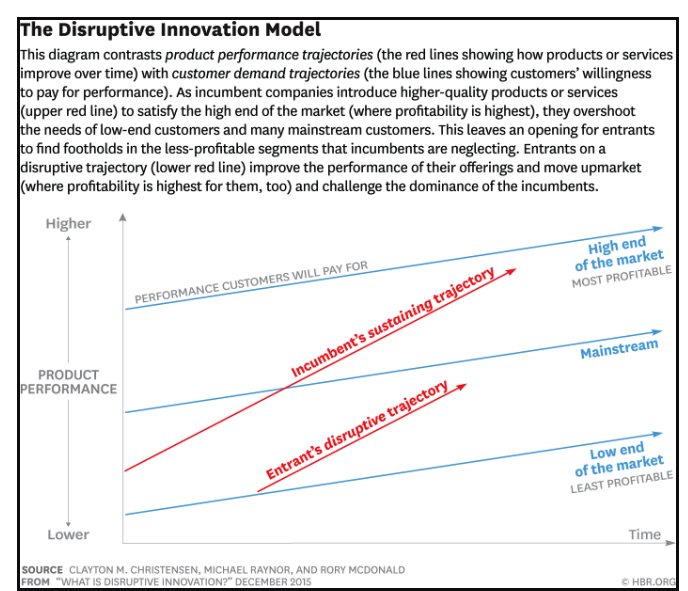

Fig. 3. Disruptive theory based on Christensen et al (2015) [2] 
According to the disruptive innovation model, new effort of conservation shall be cheaper than the previously available conservation efforts by other universities. While other universities are focusing on green technology and machinery, UNNES tries to disrupt this norm by introducing cultural and characters conservation. The complete model of the disruption is as follows:

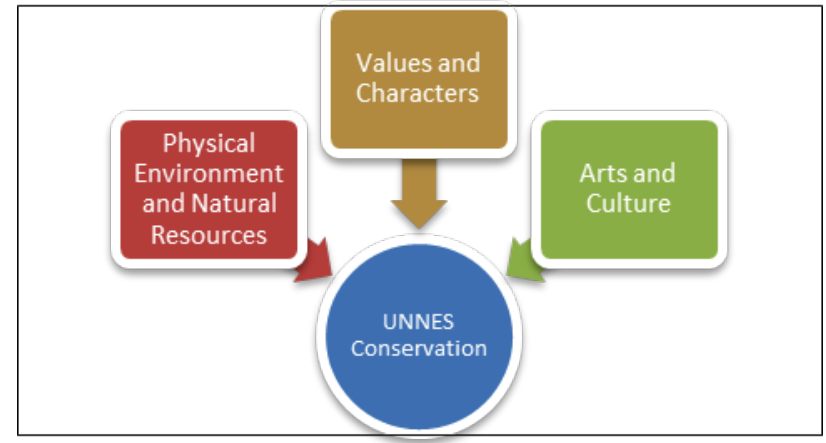

Fig. 4. Conservation model at UNNES

This model, we believe have not been adopted by other universities in Indonesia or in the world. Hence, we really hope that the disruptive innovation might work here and other universities will adopt and catch up.

\section{Conclusions}

This paper has a single purpose to deliver and we think that we have delivered it although we have to admit that it is not comprehensive. The theory of disruption by Christensen et al (2015) has led us to believe that UNNES cannot afford the mainstream ways of doing conservation such as providing high-tech waste management machinery or buying expensive solar cells for all the buildings [2]. However, UNNES is able to provide a lower cost conservation i.e. cultural and characters conservation. This type of low point of entrance fits the theory of disruption and we expect that this model will work as well as the more expensive model and even better.

\section{Reference}

1. Akib, N.A.M, Biodiversity in crisis: conservation challenges in the 21st century, Available online at https://cgss.usm.my/images/BIODIVERSITY IN C RISIS.pdf (2016)

2. Christensen, C. M., Raynor, M. E., \& McDonald, R. What is disruptive innovation, Harvard Business Review, 93(12), 44-53 (2015)

3. Geburek, T., \& Turok, J., Conservation and management of forest genetic resources in Europe. Available online at http://forest-genetic-resourcestraining-

guide.bioversityinternational.org/fileadmin/bioversit yDocs/Training/FGR TG/additional materials/Geb urekTurok/6InsituExsitu496-670.pdf (2005)

4. Haum, R., \& Petschow, U., Lead markets for environmental technologies: The case of the particulate filter for Diesel passenger cars. IÖW (2003)

5. Holland, A., \& Rawles, K., Walking the talk: Philosophy of conservation on the Isle of Rum. Worldviews: Global Religions, Culture, and Ecology, 8(2), 280-297 (2004)

6. Kahneman, D., Thinking, fast and slow. Macmillan. (2011)

7. King, A. A., \& Baatartogtokh, B., How useful is the theory of disruptive innovation?.MIT Sloan Management Review, 57(1), 77. (2015)

8. Popescu, A. Innovative solutions to prevent and reduce water pollution by application of ecological textile finishing technologies and wastewater treatment. Available online at https://www.interregeurope.eu/fileadmin/ user_upload/tx_tevprojects/library/Application $\% 20$ o f\%20ecological $\% 20$ finishing $\% 20$ and $\% 20$ wastewate r\%20treatment.pdf (2017)

9. World Bank, What a waste: a global review of solid waste management. Available online at http://siteresources.worldbank.org/INTURBANDE VELOPMENT/Resources/3363871334852610766/Chap3.pdf (2012) 